\title{
Measurement of crude protein requirement of cockerel finishers by two empirical methods
}

\author{
R. I. SALAMI \\ Animal Science Division, Department of Agricultural Education, Emmanuel Alayande College of \\ Education (formerly Oyo State College of Education, Oyo), Oyo State, Nigeria
}

\begin{abstract}
Two empirical methods, namely the orthodox or traditional and diet dilution technique, were used to measure the responses of 96 14-week-old Black Olympian cockerel finishers to graded dietary crude protein $(\mathrm{CP})$ levels of $16,18,20$ and 22 per cent on airdry basis in a 6-week trial. The diets were isocaloric ( $c a$ $2600 \mathrm{kcal} \mathrm{kg}^{-1}$ metabolisable energy). Both methods indicated that weight gains, feed conversion ratio, and protein efficiency ratio were optimized by diets containing 18 per cent $\mathrm{CP}$ level at minimal cost of feed per unit gain. The results, thus, confirm that both methods are equally good in predicting the CP requirements of finishing cockerels.
\end{abstract}

Original scientific paper. Received 25 Oct 05 ; revised 10 Dec 08

\section{RÉSUMÉ}

SAlami, R. I.: Mesure du besoin de protéine brute des modules de finition de coq a partir de deux méthodes empiriques. Deux méthodes empiriques, à savoir l'orthodoxe ou traditionnelle et la technique de régime de dilution ont été utilisées pour mesurer les réponses de quatre-vingt-seize coqs d'olympiques noirs de modules de finition de 14 semaines d'age au niveau diététique de la protéine brute (PB) de 16, 18, 20 et de $22 \%$ sur la base séchée à l'air dans une épreuve de 6 semaines. Les régimes étaient isocaloriques ( $c a$ énergie métabolisable de 2600 $\mathrm{kcal} / \mathrm{kg}$ ). Les deux méthodes ont indiqué que des gains de poids, le ratio de conversion d'alimentation et le rapport d'efficacité de protéine ont été optimisés par des régimes contenant le niveau de $18 \%$ PB au coût minimal d'alimentation par gain d'unité. Les résultats confirment ainsi que les deux méthodes sont également bonnes en prévoyant les besoins en PB des coqs de finition.

\section{Introduction}

The crude protein (CP) requirement of monogastric animals, such as poultry birds, is really required for the constituent amino acids in their diets, especially the essential ones. Unlike ruminant animals, monogastrics cannot manufacture enough essential amino acids to satisfy their needs for maintenance and production processes. Hence, it becomes imperative to measure accurately, the essential amino acid or $\mathrm{CP}$ requirements or both of the monogastrics without interfering unduly with the methodology-related factor(s).

The orthodox or traditional method most commonly used for formulating experimental diets in the $\mathrm{CP}$ or energy requirement studies involves adjusting dietary proportions of protein or energy concentrates or both to produce graded levels of protein or energy or both (Olomu, 1977; Njike, 1981; Ojewola \& Longe, 1999). A variant of this approach, commonly used in amino acid requirement studies, is the "progressive supplementation technique" (D’Mello, 1982). It entails formulating a 'basal diet' (purified or conventional) in which the test amino acid is deficient enough to allow for graded additions of the feed-graded 'synthetic form' of the amino acid under assay (Dean \& Scott, 1965; Hewitt \& Lewis, 1972). According to Fisher \& Morris (1970) and Gous (1980), test diets produced by these traditional procedures do not have similar amino acid balance or energy content or both, and this

Ghana Jnl agric. Sci. 41, 237-242 
might also interfere with the dose-related responses of the recipient animals. To avoid this and other limitations inherent in the orthodox procedures (Fisher \& Morris, 1970; Gous, 1980) for formulating diets in requirement studies, another method, the diet dilution technique, was developed and described by Fisher \& Morris (1970). It has largely been used in the study of amino acid requirements (Fisher \& Morris, 1970; Gous, 1980). It involves the dilution of a highprotein "summit diet" with an isoenergetic lowprotein or protein-free mixture to produce the test diets for estimating 'requirements'.

In his review, which compared both procedures, D'Mello (1982) concluded that both methods would yield substantially similar results, and they are equally acceptable for measuring amino acid requirements of poultry birds. Similarly, Salami (1985) reported that the traditional method and diet dilution technique are equally good in estimating the tryptophan requirements of young broiler chickens. On the strength of this evidence, the diet dilution technique has also been applied to study the $\mathrm{CP}$ requirements of growing cockerels (Salami \& Boorman, 1999) and cockerel starters (Salami, Akindoye \& Hamzat, 2002), crude protein and energy requirements of cockerel starters (Salami, Akindoye \& Akanni, 2003) and cockerel finishers (Salami, personal communication). However, no study has to date been reported that compared both methods for measuring $\mathrm{CP}$ requirement. It is against this background information that this study compares both methods to determine the $\mathrm{CP}$ requirements of cockerel finishers.

\section{Materials and methods}

The experimental diets were formulated either by the orthodox or diet dilution method. Diets A, B, $\mathrm{C}$ and D (Table 1) were formulated using the orthodox method and contained 16, 18, 20 and 22 per cent CP, respectively (air-dry basis). Diets E, F, $\mathrm{G}$ and $\mathrm{H}$, which also contained 16, 18, 20 and 22 per cent $\mathrm{CP}$ respectively, were formulated using the diet dilution method by mixing a 28 per cent
$\mathrm{CP}$ summit diet and a 2.51 per cent $\mathrm{CP}$ dilution mixture (whose compositions are shown in Table 2 ) in the proportions shown in Table 3. All diets were isocaloric ( $c$ a $2600 \mathrm{kcal} \mathrm{kg}^{-1} \mathrm{ME}$ ).

Ninety-six, 14-week-old Black Olympian cockerel finishers were put into eight experimental groups of the same mean initial live weight. The treatment diets coded $\mathrm{A}$ to $\mathrm{H}$ were randomly applied to the groups in a trial that lasted for 6 weeks. Each diet was fed to three replicates of four birds each. The birds per replicate were housed in twos per cage compartment measuring $30 \mathrm{~cm} \times 38 \mathrm{~cm} \times 43 \mathrm{~cm}$ for breadth, length and height respectively. The two-tier battery cage was placed inside an open-sided poultry house. Feeding and watering were administered $a d$ libitum. Vaccinations (against Newcastle, Gumboro and fowl pox diseases) and medications (against coccidiosis and worm infestation) for the birds were administered as and when due as described by Salami \& Oyewole (1997).

The initial and final body weights of individual birds at 14th and 20th weeks of age respectively were measured to compute the average daily weight gain. Feed intake was also measured weekly to calculate the average daily feed intake. From the records of live weight gain and feed intake, feed conversion ratio (FCR) was determined. Protein efficiency ratio (PER) was also computed as weight gain per unit of protein consumed by the bird (i.e. weight gain divided by protein intake). Protein intake was derived as dietary crude protein content multiplied by feed intake.

The costs of various treatment diets were also computed using market prices of the feed ingredients at the time of experiment (Tables 1 and 2).

Response data were analysed using ANOVA (Steel \& Torrie, 1980) and significant differences in the treatment means were evaluated using the Duncan's Multiple Range Test.

\section{Results and discussion}

This trial sets out to compare the orthodox and 
TABLE 1

Percentage Composition of Treatment Diets Produced by Orthodox Method

\begin{tabular}{|c|c|c|c|c|c|}
\hline Feed ingredient & ${ }^{a} k g^{-1}$ & $A$ & $B$ & $C$ & $D$ \\
\hline Maize $(\mathrm{CP}=9 \%)$ & 44.00 & 38.00 & 38.00 & 38.00 & 38.00 \\
\hline Palm kernel cake $(\mathrm{CP}=18 \%)$ & 6.50 & 10.00 & 14.00 & 11.00 & 10.00 \\
\hline Groundnut cake $(\mathrm{CP}=45 \%)$ & 40.00 & 8.00 & 10.00 & 14.00 & 18.50 \\
\hline Fish meal $(\mathrm{CP}=65 \%)$ & 170.00 & 3.50 & 4.00 & 4.00 & 4.00 \\
\hline Blood meal $(\mathrm{CP}=80 \%)$ & 28.00 & 3.00 & 4.00 & 5.00 & 6.00 \\
\hline Maize offal $(\mathrm{CP}=11 \%)$ & 20.00 & 19.50 & 13.00 & 9.00 & 5.00 \\
\hline Rice offal $(\mathrm{CP}=4 \%)$ & 3.50 & 14.00 & 13.00 & 14.50 & 14.50 \\
\hline Oyster shell & 7.00 & 1.50 & 1.50 & 1.50 & 1.50 \\
\hline Bone meal & 30.00 & 2.00 & 2.00 & 2.00 & 2.00 \\
\hline Salt & 18.00 & 0.25 & 0.25 & 0.25 & 0.25 \\
\hline Premix & 450.00 & 0.25 & 0.25 & 0.25 & 0.25 \\
\hline Total & - & 100.00 & 100.00 & 100.00 & 100.00 \\
\hline $\mathrm{kg}^{-1}$ & - & 33.62 & 34.48 & 35.62 & 36.63 \\
\hline \multicolumn{6}{|l|}{ Calculated fractions } \\
\hline Crude protein $(\%)$ & & 16.20 & 18.09 & 20.09 & 22.07 \\
\hline Metabolizable energy $\left(\mathrm{kcal} \mathrm{kg}^{-1}\right)$ & & 2599.72 & 2606.40 & 2606.87 & 2618.22 \\
\hline Crude fibre $(\%)$ & & 8.97 & 8.48 & 8.33 & 7.94 \\
\hline Lysine $(\%)$ & & 0.70 & 0.83 & 0.95 & 1.06 \\
\hline Methionine (\%) & & 0.27 & 0.30 & 0.31 & 0.34 \\
\hline
\end{tabular}

${ }^{\mathrm{a}}$ Denotes Nigerian currency (Naira), 100 Kobo $=\$ 1.00$

diet dilution methods for determining the $\mathrm{CP}$ requirement of finishing cockerels. Table 4 shows the effects of the graded CP levels, as per the two methods, on the response criteria measured. As observed in the earlier studies (Salami \& Boorman, 1999; Salami, personal communication), the response criteria were improved significantly as the $\mathrm{CP}$ level increased up to 18 per cent $\mathrm{CP}$ level. Beyond this level, performance in weight gain, feed conversion ratio and protein efficiency ratio tended to deteriorate, indicating that protein in excess of requirement was harmful to the birds. Thus, Diets B and F, which contained 18 per cent $\mathrm{CP}$, satisfied the cockerel finishers' requirement. This dietary CP level also minimizes the feed cost per unit of weight gain as in antecedent reports; for example, Salami \& Boorman (1999).
The similarity in the response pattern of cockerels to treatment diets produced by both methods confirms that they are equally good in predicting the $\mathrm{CP}$ requirements of the finishing cockerels. This finding, therefore, agrees with that of Salami (1985) and disagrees with the claims of some authors (e.g. Fisher \& Morris, 1970; Gous, 1980) that the diet dilution technique is an improved method over the traditional one. Thus, the methods used to formulate test diets in requirement studies do not seem to contribute [unlike environmental, animal and dietary factors as per literature review of Salami (1985)] to the disparities noticed in the quoted requirement values for nutrients such as $\mathrm{CP}$ and amino acids. This is also in line with the conclusion of D'Mello (1982) in his review. 
TABLE 2

Percentage Composition of Summit Diet (SD) and Dilution Mixture (DM)

\begin{tabular}{|c|c|c|c|}
\hline Feed ingredient & $k^{-1}$ & $S D$ & $D M$ \\
\hline Maize $(\mathrm{CP}=9 \%)$ & 44.00 & 31.00 & - \\
\hline Palm kernel cake $(\mathrm{CP}=18 \%)$ & 6.50 & 13.00 & - \\
\hline Groundnut cake $(\mathrm{CP}=45 \%)$ & 40.00 & 29.00 & - \\
\hline Fish meal $(\mathrm{CP}=65 \%)$ & 170.00 & 7.00 & - \\
\hline Blood meal $(\mathrm{CP}=80 \%)$ & 28.00 & 6.00 & - \\
\hline Lafun $(\mathrm{CRM})(\mathrm{CP}=2 \%)$ & 27.50 & - & 62.50 \\
\hline Palm oil & 85.00 & - & 2.00 \\
\hline Rice offal $(\mathrm{CP}=4 \%)$ & 3.50 & 10.00 & 31.50 \\
\hline Oyster shell & 7.00 & 1.50 & 1.50 \\
\hline Bone meal & 30.00 & 2.00 & 2.00 \\
\hline Salt & 18.00 & 0.25 & 0.25 \\
\hline Premix & 450.00 & 0.25 & 0.25 \\
\hline Total & - & 100.00 & 100.00 \\
\hline $\mathrm{kg}^{-1}$ & - & 40.47 & 21.87 \\
\hline \multicolumn{4}{|l|}{ Calculated fractions } \\
\hline Crude protein $(\%)$ & & 28.01 & 2.51 \\
\hline Metabolizable energy $\left(\mathrm{kcal} \mathrm{kg}^{-1}\right)$ & & 2602.95 & 2601.0 \\
\hline Crude fibre $(\%)$ & & 6.76 & 11.64 \\
\hline Lysine (\%) & & 1.35 & 0.04 \\
\hline Methionine (\%) & & 0.43 & 0.02 \\
\hline
\end{tabular}

TABLE 3

Composition of Experimental Diets Produced from Summit Diet and Dilution Mixture

\begin{tabular}{|c|c|c|c|c|c|}
\hline \multirow[b]{2}{*}{$\begin{array}{l}\text { Treatment } \\
\text { diet }\end{array}$} & \multirow{2}{*}{\multicolumn{2}{|c|}{ Dietary levels of }} & \multicolumn{2}{|c|}{ Proportion of } & \multirow[b]{2}{*}{$k^{a g^{a-}}$} \\
\hline & & & $\begin{array}{l}\text { Summit } \\
\operatorname{diet}\left(g \mathrm{~kg}^{-1}\right)\end{array}$ & $\begin{array}{c}\text { Dilution } \\
\text { mixture }\left(g \mathrm{~kg}^{-1}\right)\end{array}$ & \\
\hline $\mathrm{E}$ & 16.02 & 26.02 .03 & 530.0 & 470.00 & 31.73 \\
\hline $\mathrm{F}$ & 18.00 & 2602.18 & 607.50 & 392.50 & 33.17 \\
\hline G & 20.00 & 2602.34 & 685.90 & 314.10 & 34.65 \\
\hline $\mathrm{H}$ & 22.00 & 2602.49 & 764.40 & 235.60 & 36.08 \\
\hline
\end{tabular}

${ }^{\mathrm{a}} \mathrm{Feed}$ cost $\mathrm{kg}^{-1}$ is computed from Table 2 .

Conclusively, the two methods used now to devise treatment diets had about the same effects, indicating that both are equally good in estimating $\mathrm{CP}$ requirements of finishing cockerels, which is 18 per cent in diets containing $2600 \mathrm{kcal} \mathrm{kg}^{-1}$ metabolizable energy.

\section{Acknowledgement}

The author is grateful to Mr Sola Akindoye and Miss Kemi Alade for assisting in managing the 
experimental birds.

\section{REFERENCES}

D'Mello, J. P. F. (1982) A comparison of two empirical methods of determining amino acid requirements. Wld's Poult. Sci. J. 38, 114-119.

Dean, W. F. \& Scott, H. M. (1965) The development of an amino acid reference diet for the early growth of chicks. Poult. Sci. 44, 803-808.

Fisher, C. \& Morris, T. R. (1970) The determination of the methionine requirement of laying pullets by a diet dilution technique. Br. Poult. Sci. 11, 6782.

Gous, R. M. (1980) An improved method for measuring the response of broiler chickens to increasing dietary concentration of amino acid. In Proceedings of 6th European Poultry Conference, Hamburg. III, 32-39.

Hewitt, D. \& Lewis, D. (1972) The effect of dietary lysine level, restriction of food intake and sampling time on the levels of amino acid in the blood plasma of chicks. Br. Poult. Sci. 13, 387-398.

Njike, M. C. (1981) Crude protein requirements of egg-type baby chicks under Nigerian (tropical) environment. Niger. J. Anim. Prod. 8(1), 78-83.

Ojewola, G. S. \& Longe, O. G. (1999) Protein and energy in broiler starter diets: Effects on growth performance and nutrient utilization. Niger. J. Anim. Prod. 26, 23-28.

Olomu, J. M. (1977) Determination of optimum protein and energy levels for broiler finishers in the tropical environment. Niger. J. Anim. Prod. 4(1), 239-255.

Salami, R. I. (1985) The response of young chickens to tryptophan (M Phil Thesis). University of Nottingham School of Agriculture, Sutton Bonington, UK.

Salami, R. I. \& Oyewole, S. O. O. (1997) Evaluation of poultry visceral offal meal as a substitute for fish meal in grower pullets' diets. Niger. J. Anim. Prod. 24(1), 
20-25.

Salami, R. I. \& Boorman, K. N. (1999) Crude protein requirement of growing cockerels by diet dilution technique. Trop. J. Anim. Sci. 1(2), 63-72.

Salami, R. I., Akindoye, O. \& Hamzat, S. A. (2002) The crude protein requirement of the starter cockerels with diets containing $2600 \mathrm{kcal} \mathrm{kg}^{-1}$ metabolizable energy level. Trop. Anim. Prod.
Invest. 5, 59-66.

Salami, R. I., Akindoye, O. \& Akanni, E. O. (2003) Protein and energy requirements of some cockerel starters in the tropics. Ghana Jnl agric. Sci. 36, 6977.

Steel, R. G. D. \& Torrie, J. H. (1980) Principles and procedures of statistics, 2nd edn. McGraw-Hill, New York. 